\title{
An investigation on weld quality characteristics of pulsed current micro plasma arc welded austenitic stainless steels
}

\author{
Kondapalli Siva Prasad $^{\mathrm{a}^{*}}$, Chalamasetti Srinivasa Rao ${ }^{\mathrm{b}}$, Damera Nageswara Rao ${ }^{\mathrm{c}}$ \\ ${ }^{a}$ Department of Mechanical Engineering, Anil Neerukonda Institute of Technology \& Sciences, Visakhapatnam, 531 162, INDIA \\ ${ }^{b}$ Department of Mechanical Engineering, Andhra University, Visakhapatnam,530 002, INDIA \\ ${ }^{c}$ Centurion University of Technology \& Management,Odisha, INDIA \\ *Corresponding Author Email:kspanits@gmail.com, Contact No: 91-9849212391, Fax No: 91-08933-226395
}

\begin{abstract}
Micro Plasma Arc Welding (MPAW) is one of the important arc welding process commonly used in sheet metal industry for manufacturing metal bellows, metal diaphragms etc. The present work discusses about the weld quality characteristics of various austenitic stainless steels namely AISI 304L, AISI 316L, AISI 316Ti, AISI 321 which are commonly used for manufacturing of metal bellows. Square butt joint is used in the welding and no filler wire is used. Welding is carried out at fixed values of input parameters and same thickness of $0.25 \mathrm{~mm}$ for all the steels. Peak current, background current, pulse rate and pulse width are considered as the main welding process parameters of MPAW process, where as weld bead geometry, microstructure, grain size, hardness and tensile properties are considered as weld quality characteristics. Results reveal that out of all the materials considered in the study AISI 304L attains better weld quality characteristics for same welding conditions.
\end{abstract}

Keywords: Pulsed current micro plasma arc welding, microstructure, grain size, hardness, tensile properties.

DOI: http://dx.doi.org/10.4314/ijest.v4i2.12

\section{Introduction}

Around the beginning of the twentieth century, it was discovered that by adding at least $12 \%$ chromium by weight steels become more corrosion resistant than common carbon steels. The addition of chromium caused the spontaneous formation of a passive protective layer, which reduced the rate of surface dissolution (Sadek and El-Sheikh, 2000). As the science of metallurgy progressed, it was found that by further alloying steels with elements such as nickel, molybdenum, copper, titanium, aluminum, silicone, niobium, nitrogen, sulfur and selenium, other desirable properties could be selectively created. While stainless steels are generally defined as an iron alloy containing a minimum of $12 \mathrm{wt}$ \% chromium, they may be further categorized into several subcategories. These categories are martensitic, ferritic, duplex, precipitation hardenable and austenitic.

Austenitic stainless steels are probably the most commonly used material of all the stainless steels. The most common austenitic family, the 300 series, is an iron-chrome-nickel system. Austenitic stainless steels are considered to be more resistant to corrosion due to the high wt. \% chromium and nickel content typically (18-20 and 8-12 respectively). They are non magnetic and nonhardenable by heat treatment. However, they can be hardened significantly by cold working. Austenitic stainless steels are used extensively in petrochemical, nuclear, and corrosive chemical environments (Palaniappan et al., 1996; Reddy, 2000; Vannan and Thangavel, 1978). Austenitic stainless steels are further defined by the carbon content as; "L" grades, straight grades and " $H$ " grades. The $\mathrm{L}$ grades contain $\leq 0.03 \mathrm{wt} \% \mathrm{C}$, the straight grades contain $0.03-0.08 \mathrm{wt} \% \% \mathrm{C}$ and the $\mathrm{H}$ grades contain anywhere from $0.04-0.10 \mathrm{wt} . \% \mathrm{C}$. The higher carbon content of the $\mathrm{H}$ grades produces a harder and more wear resistant material. The increased carbon also helps the material hold its strength at high temperatures and is therefore often used in high temperature applications. However, the increase in carbon leads to problems in the Heat Affected Zone (HAZ) of the welds and is discussed in the following section. The lower carbon content of the "L" grades is specifically designed for improved weldability. High carbon 
grades are often employed where harder, wear resistant, or high temperature applications exist. Low carbon stainless steels such as $304 \mathrm{~L}, 316 \mathrm{~L}$ are routinely used where intergranular corrosion is of concern.

Primarily, arc welding has long been considered as a viable process for joining ferrous materials; austenitic stainless steels are no exception. Inherent in the arc welding process however, are certain problems, which keep it from being an "ideal" process. Typically, in all arc welding processes, problems such as chemical inhomogeneities in the weld, microporosity, cold laps, microfissures, and hot cracks reduce the quality of the joint (Malik, 1981). Austenitic stainless steels are particularly prone to the hot cracking phenomenon. It has been determined however, that hot cracking may be reduced in austenitic stainless steel weldments by using filler materials that contain a small percentage of retained ferrite (Sadek and El-Sheikh, 2000; Vannan and Thangavel, 1978; David et al., 1979). Although appropriate filler materials have been developed, problems still arise especially in the root of weldments, where the filler material may be diluted by the high amount of austenite in the parent material. Furthermore, the slower cooling rate at the root with respect to the rest of the weld nugget reduces the amount of retained ferrite and increases the likelihood of hot cracking (Vannan and Thangavel, 1978; David et al., 1979). While filler materials are able to compensate for undesired changes in the microstructure of the solidified region, they cannot prevent the microstructural changes in the HAZ. When steel is held at critical temperature range $\left(600-800^{\circ} \mathrm{C}\right)$ chromium precipitates out of the matrix and forms chrome carbides along the grain boundaries. The formation of chrome carbides produces a chemical inhomogeneity in the surrounding grains; they become depleted in chromium with respect to the base material. When these precipitates cause the surrounding areas to have less than about 13 wt. \% chromium, the areas become susceptible to corrosion. Keeping the carbon content low reduces this problem by reducing the amount of chromium being precipitated along the grain boundaries.

The plasma welding process was introduced to the welding industry in 1964 as a method of bringing better control to the arc welding process in lower current ranges. Today, plasma retains the original advantages it brought to the industry by providing an advanced level of control and accuracy to produce high quality welds in both miniature and pre precision applications and to provide long electrode life for high production requirements at all levels of amperage. Plasma welding is equally suited to manual and automatic applications. It is used in a variety of joining operations ranging from welding of miniature components to seam welding to high volume production welding and many others.

.Singh et al. (2003) evaluated fatigue life on Gas Tungsten Arc Welded (GTAW) load-carrying cruciform joints of AISI 304L stainless steel with Lack of Penetration (LOP) using conventional S-N and crack initiation-propagation (I-P) methods. Sonsuvit et al. (2005) investigated the effects of TIG pulse welding parameters and nitrogen gas mixed in Argon shielding gas on weld bead formation and microstructure of weld metals of AISI 304L stainless steels at the 10-h welding position. Ahmad et al. (2007) reported that $\mathrm{Zr}(\mathrm{Cr}, \mathrm{Fe}) 2$ intermetallic compound and $\mathrm{Zr}_{2} \mathrm{Fe}-\mathrm{Zr}_{2} \mathrm{Ni}$ eutectic phases have been observed in the molten zone of the TIG welded joints of the Zircaloy-4 and stainless steel 304L. Giridharan and Murugan (2009) adopted a quasi-Newton numerical optimization technique for optimizing pulsed gas tungsten arc welding (pulsed GTAW) process parameters to obtain optimum weld bead geometry with full penetration in welding of stainless steel (304L) sheets of $3 \mathrm{~mm}$ thickness. Design of experiments based on central composite rotatable design was employed for the development of a mathematical model correlating the important controllable pulsed GTAW process parameters like pulse current, pulse current duration and welding speed with weld bead parameters such as penetration, bead width, aspect ratio and weld bead area of the weld. Velasco et al. (2009) analysed the effect of welding on mechanical properties of ribbed bars of two cold-deformed austenitic stainless steels (new, low-nickel AISI 204Cu and traditional 304L types) and two duplex stainless steels (SAF 2205 type, cold and hot-worked). Welds had been carried out using shielded metal arc welding. The effect of welding on local mechanical properties had been studied using a universal hardness equipment, measuring universal and Vickers hardness, elastic and plastic energies and Young modulus. Lee et al. (2004) used split-Hopkinson pressure bar to investigate the effects of strain rate in the range of $10^{-3} \mathrm{~s}^{-1}$ to $8 \times 10^{-3} \mathrm{~s}^{-1}$ and welding current mode upon the dynamic impact behavior of Plasma Arc Welded (PAW) 304L stainless steel (SS) weldments. Stress-strain curves were plotted for different strain rates and welding parameters and Optical Microscopy (OM), Scanning Electron Microscopy (SEM) and Transmission Electron Microscopy (TEM) techniques were used to analyze the microstructure and fracture characteristics of the weldments.

The main objective of the present paper is to compare the weld quality characteristics of various austenitic stainless steels of same thickness using same welding conditions. All the austenitic steels used in the present study are used for manufacturing metal bellows, which are used in thermal expansion joints. The present paper focuses on comparing the weld quality characteristics of AISI 304L, AISI 316L, AISI 316Ti and AISI 321 steels welded using Pulsed Current MPAW process. As a part of weld quality characteristics only static properties like weld bead geometry, microstructure, grain size, hardness and tensile properties are considered in the present work.

\section{Experimental Details}

Austenitic stainless steels (AISI 304L, AISI 316L, AISI 316Ti, AISI 321) sheets of $100 \mathrm{x} 150 \mathrm{x} 0.25 \mathrm{~mm}$ are welded autogenously with square butt joint without edge preparation. The chemical compositions and tensile properties of AISI 304L, AISI 316L, AISI 316Ti, AISI 321 austenitic stainless steel sheets is given in Table 1a and Table 1b which were procured from Salem steel plant, India. High purity argon gas (99.99\%) is used as a shielding gas and a trailing gas right after welding to prevent absorption of oxygen and nitrogen from the atmosphere. The welding has been carried out under the welding conditions presented 
in Table 2. There are many influential process parameters which affect the weld quality characteristics of Pulsed Current MPAW process like peak current, background current, pulse rate, pulse width, flow rate of shielding gas, flow rate of purging gas, flow rate of plasma gas, welding speed etc. From the earlier works (Balasubramanian et al., 2006, 2010; Giridharan and Murugan, 2009; Prasad et al., 2011a,b,c, 2012) carried out on Pulsed Current MPAW it was understood that the peak current, back current, pulse rate and pulse width are the dominating parameters which effect the weld quality characteristics. We had carried out 31 experiments considering 4 factors, five levels as per Central Composite Design (CCD) matrix of Response Surface Method (RSM) and optimized the welding parameters using optimization techniques like Hooke \& Jeeves and Genetic Algorithms for AISI 304L sheets. The values of process parameters used in this study are the optimal values obtained from our earlier papers on AIS 304L (Prasad et al., 2011a,b,c; 2012). Hence peak current, background current, pulse rate and pulse width are chosen and their values are presented in Table.3.

Table 1a Chemical composition of AISI 304L, AISI 316L, AISI 316Ti, AISI 321 (weight \%)

\begin{tabular}{|l|l|l|l|l|l|l|l|l|l|l|}
\hline Material & $\mathrm{C}$ & $\mathrm{Si}$ & $\mathrm{Mn}$ & $\mathrm{P}$ & $\mathrm{S}$ & $\mathrm{Cr}$ & $\mathrm{Ni}$ & $\mathrm{Mo}$ & $\mathrm{Ti}$ & $\mathrm{N}$ \\
\hline AISI 304L & 0.02 & 0.36 & 1.31 & 0.03 & 0.003 & 18.13 & 08.03 & -- & -- & 0.06 \\
\hline AISI 316L & 0.04 & 0.52 & 1.61 & 0.02 & 0.007 & 17.02 & 12.48 & 2.04 & -- & -- \\
\hline AISI 316Ti & 0.04 & 0.43 & 1.69 & 0.02 & 0.002 & 16.50 & 10.60 & 2.12 & 0.41 & 0.01 \\
\hline AISI 321 & 0.02 & 0.35 & 1.60 & 0.03 & 0.014 & 17.42 & 09.25 & -- & 0.32 & 0.02 \\
\hline
\end{tabular}

Table 1bTensile properties of AISI 304L, AISI 316L, AISI 316Ti, AISI 321

\begin{tabular}{|l|c|c|c|}
\hline \multicolumn{1}{|c|}{ Material } & Elongation (\%) & Yield Strength (MPa) & Ultimate Tensile strength (MPa) \\
\hline AISI 304L & 49 & 350 & 784 \\
\hline AISI 316L & 43 & 220 & 550 \\
\hline AISI 316Ti & 47 & 261 & 634 \\
\hline AISI 321 & 56 & 265 & 608 \\
\hline
\end{tabular}

Table 2 Welding conditions

\begin{tabular}{|l|l|}
\hline \multicolumn{1}{|c|}{ Power source } & $\begin{array}{c}\text { Secheron Micro Plasma Arc Machine } \\
\text { (Model: PLASMAFIX 50E) }\end{array}$ \\
\hline Polarity & DCEN \\
\hline Mode of operation & Pulse mode \\
\hline Electrode & $2 \%$ thoriated tungsten electrode \\
\hline Electrode Diameter & $1 \mathrm{~mm}$ \\
\hline Plasma gas & Argon \& Hydrogen \\
\hline Plasma gas flow rate & 6 Liters $/$ min \\
\hline Shielding gas & Argon \\
\hline Shielding gas flow rate & 0.4 Liters $/ \mathrm{min}$ \\
\hline Purging gas & Argon \\
\hline Purging gas flow rate & 0.4 Liters $/ \mathrm{min}$ \\
\hline Copper Nozzle diameter & $1 \mathrm{~mm}$ \\
\hline Nozzle to plate distance & $1 \mathrm{~mm}$ \\
\hline Welding speed & $260 \mathrm{~mm} / \mathrm{min}$ \\
\hline Torch Position & Vertical \\
\hline Operation type & Automatic \\
\hline
\end{tabular}

Table 3 Important weld parameters

\begin{tabular}{|l|l|c|}
\hline \multicolumn{1}{|c|}{ Input Factor } & \multicolumn{1}{c|}{ Units } & Value \\
\hline Peak Current & Amperes & 7 \\
\hline Background Current & Amperes & 4 \\
\hline Pulse rate & Pulses/second & 40 \\
\hline Pulse width & $\%$ & 50 \\
\hline
\end{tabular}

\subsection{Measurement of Weld Bead Geometry}

Sample preparation and mounting was done as per ASTM E 3-11 standard. Three samples at a distance of $25 \mathrm{~mm}$ to each other are cut at the middle of the welded joint. The samples are mounted using Bakelite powder. After standard metallurgical polishing process, Oxalic acid is used as the etchant to reveal weld bead geometry. The weld pool geometries were measured using 
Metallurgical Microscope, Make: Dewinter Technologie, Model No. DMI-CROWN-II. A typical weld bead geometry is shown in Figure 1.The values of weld bead geometry are measured at three different locations of the same sample and their average values are reported in Table 6. Figures 2a, 2b, 2c,2d indicates welded joint of AISI 304L,AISI 316L, AISI 316Ti, AISI 321 respectively.

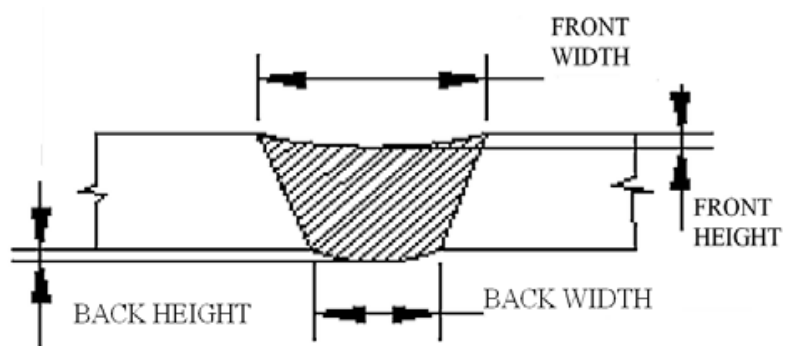

Fig.1 Typical weld bead geometry (Giridharan and Murugan, 2009)

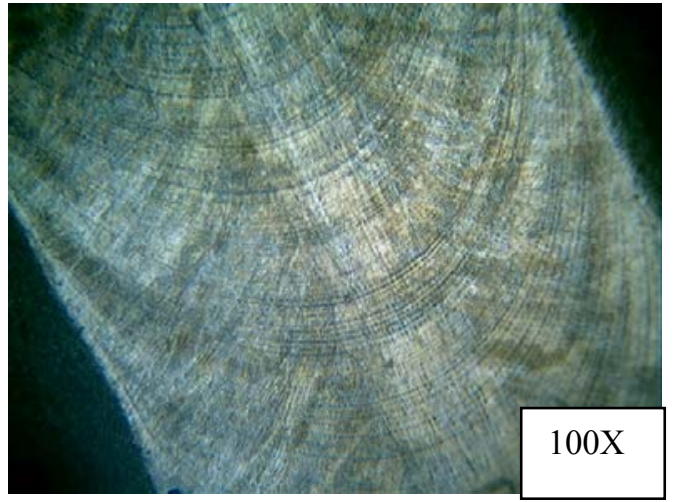

Fig.2aWeld bead of AISI 304L (Front side)

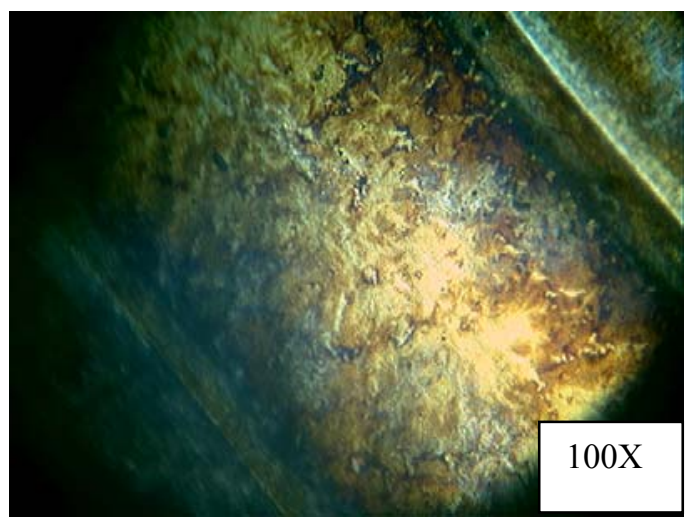

Fig.2c Weld bead of AISI 316Ti (Front side)

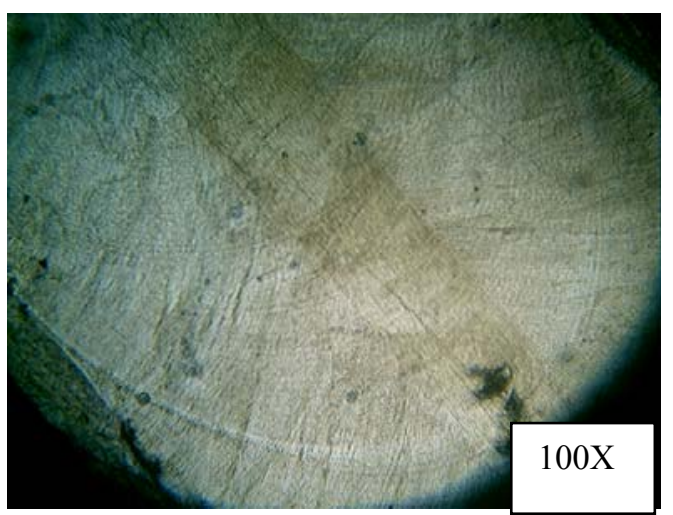

Fig.2b Weld bead of AISI 316L (Front side)

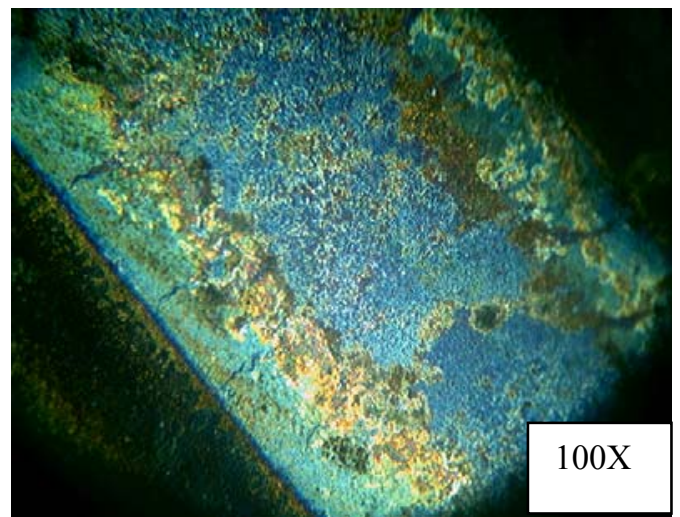

Fig.2d Weld bead of AISI 321(Front side)

The weld bead geometry dimensions of AISI 304L is better compared to other austenitic stainless steel because of low carbon and nickel content.

\subsection{Microstructure measurement}

For Microstructure measurement ASTM E 407 was followed for etching, along with ASM Metal Hand Book, Volume 9. The samples at a distance of $25 \mathrm{~mm}$ to each other are cut at the middle of the welded joint. For revealing the Microstructure the weld samples are mounted using Bakelite and polishing was done according to standard Metallurgical procedure. Oxalic Acid was used as an etchant. For revealing the Microstructure, Electrolytic Etching was done. The Microstructure was measured using Metallurgical Microscope at a magnification of 100X. Fig.3a,3b,3c, 3d indicates the microstructures of AISI 304L,AISI 316L, AISI 316Ti, AISI 321 respectively. The left portion in the Fig.3a, 3b indicates weld fusion zone and right portion indicates HAZ. 


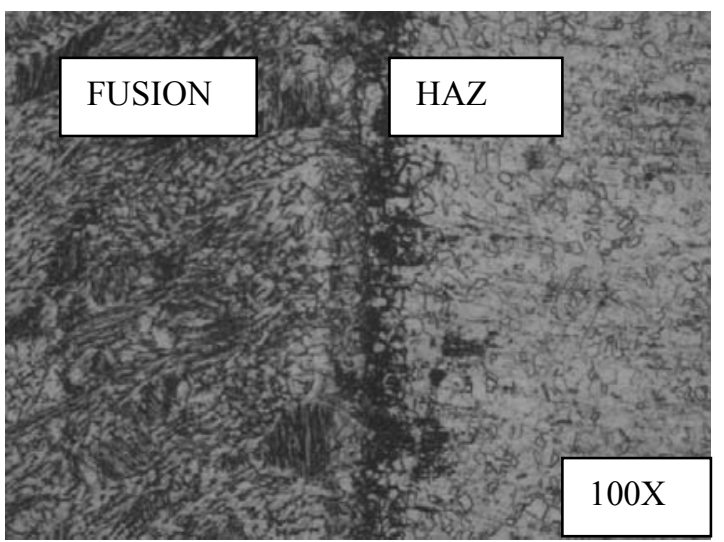

Fig.3a Microstructure of AISI 304L

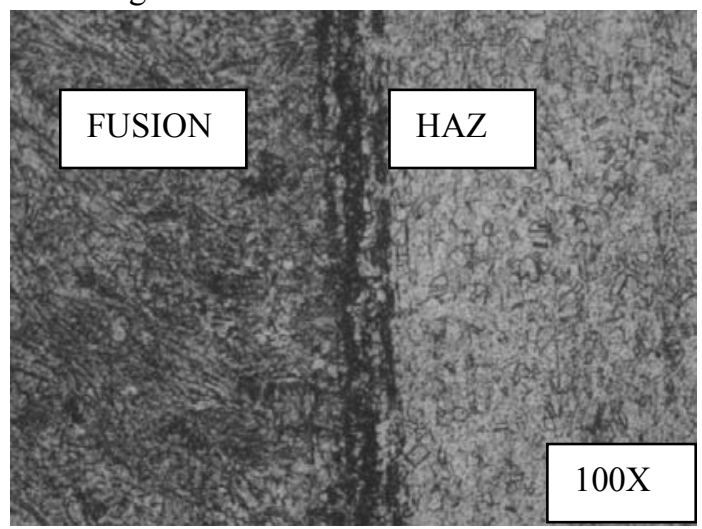

Fig.3c Microstructure of AISI 316Ti

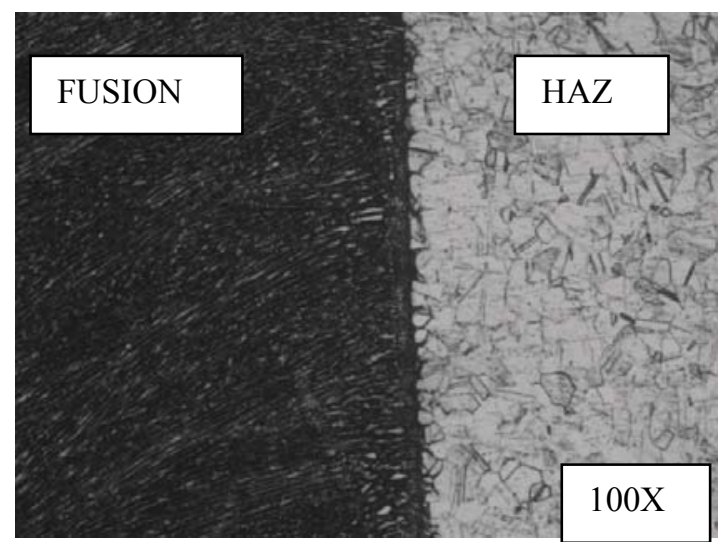

Fig.3b Microstructure of AISI 316L

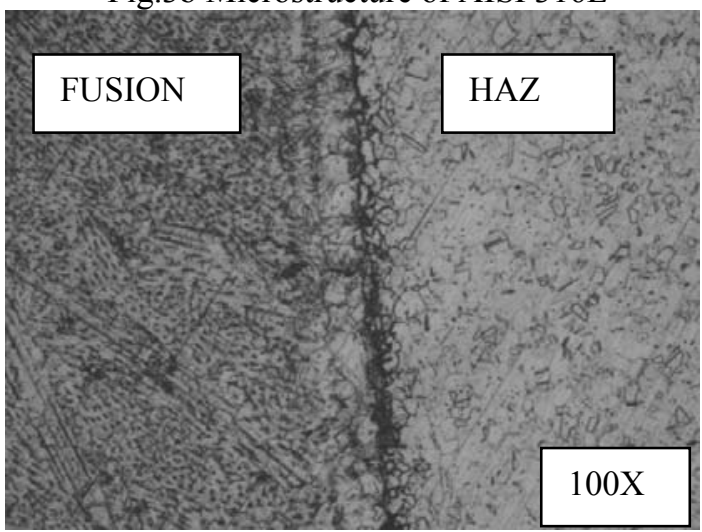

Fig.3d Microstructure of AISI 321

\subsection{Grain Size measurement}

The samples at a distance of $25 \mathrm{~mm}$ to each other are cut at the middle of the welded joint. In order to reveal the grains, polishing was done according to standard Metallurgical procedure and Etching was done as per ASTM E407. Electrolytic was done using Nitric Acid for about 1 minute. Scanning Electron Microscope, Make: INCA Penta FETx3, Model: 7573 is used to measure the fusion zone grain size and parent metal. Figure $4 a, 4 b, 4 c, 4 d$ indicates the fusion zone grain size at welding speeds of AISI $304 \mathrm{~L}$, AISI 316L, AISI 316Ti, AISI 321 respectively. As the grains in some parts of the weld fusion zone are elongated, an average value was reported by measuring grain size (perimeter) at different locations in the fusion zone of each sample.

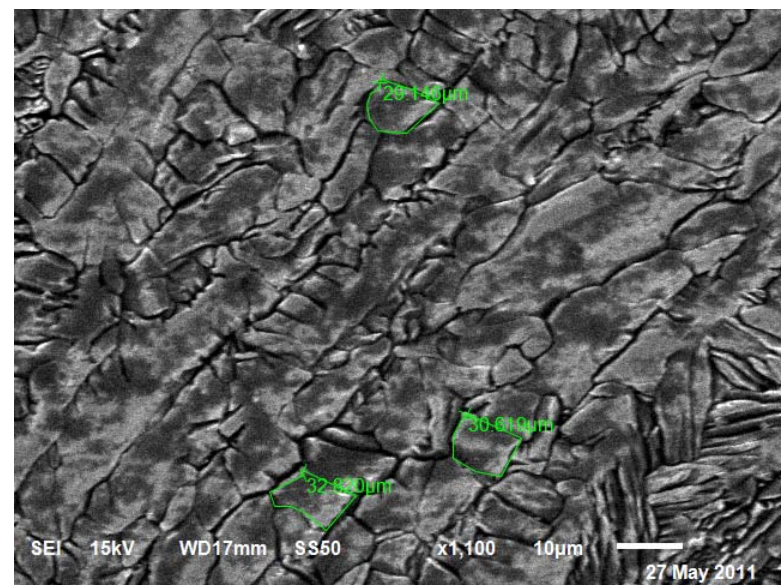

Fig.4a
Grain size of AISI 304L

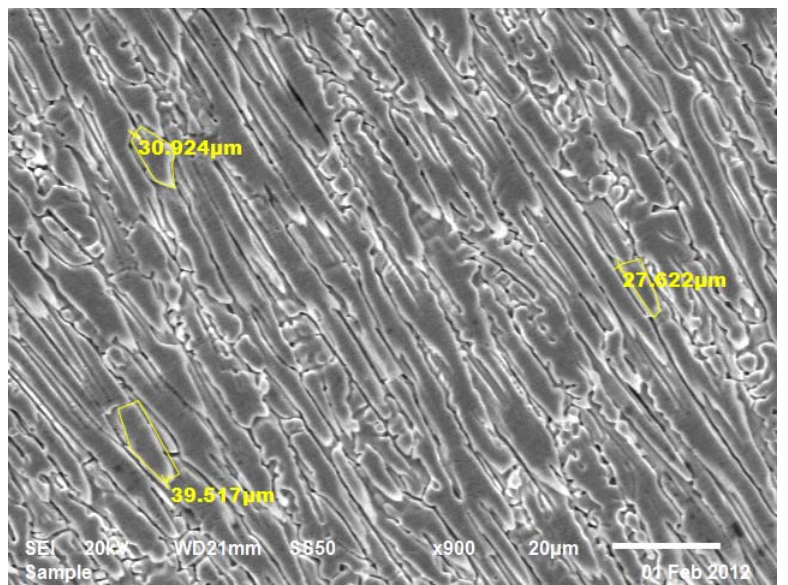

Fig.4b Grain size of AISI 316L 


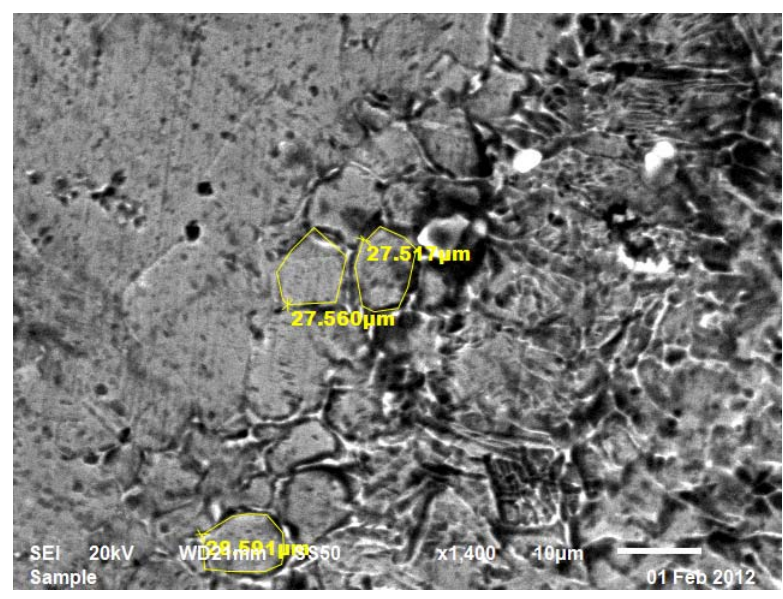

Fig.4c $\quad$ Grain size of AISI 316Ti

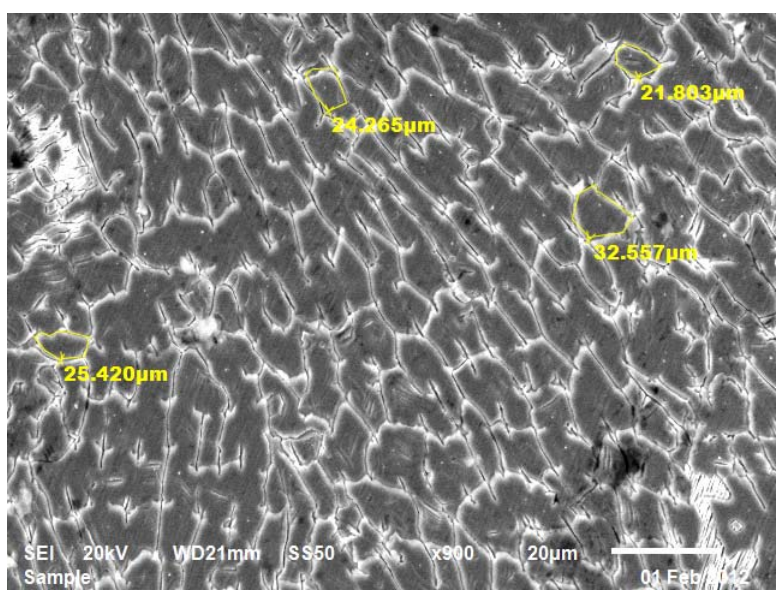

Fig.4d Grain size of AISI 321

From Figure 4a, 4b,4c,4d, it is observed that for same welding conditions, the fusion zone grain size of AISI $316 \mathrm{~L}$ is high at 33 microns and AISI 321 has the smallest size of 24 microns.

\subsection{Measurement of Vickers Micro Hardness}

Vickers Micro hardness was done as per ASTM E384. The samples at a distance of $25 \mathrm{~mm}$ to each other are cut at the middle of the welded joint and Vickers Micro Hardness values across the weld joint at an interval of $0.3 \mathrm{~mm}$ using Digital Micro Hardness testing Machine, make METSUZAWA CO LTD, JAPAN, Model No: MMT-X7 is carried out. The average values are reported in Table 4. Hardness values reported in Table 4 are measured at a load of $0.5 \mathrm{Kg}$.

Table 4 Variation of hardness values across the weld joint at $0.3 \mathrm{~mm}$ interval

\begin{tabular}{|c|c|c|c|c|c|c|c|c|c|c|}
\hline \multirow{3}{*}{ Material } & \multirow{3}{*}{$\begin{array}{c}\text { Parent } \\
\text { material } \\
\text { hardness } \\
\text { in VHN }\end{array}$} & \multicolumn{9}{|c|}{ Hardness values in VHN at different locations on the weld joint } \\
\hline & & \multicolumn{2}{|c|}{ HAZ zone } & \multicolumn{5}{|c|}{ Fusion zone } & \multicolumn{2}{|c|}{ HAZ zone } \\
\hline & & 1 & 2 & 3 & 4 & 5 & 6 & 7 & 8 & 9 \\
\hline AISI 304L & 176 & 204 & 217 & 216 & 201 & 203 & 207 & 213 & 206 & 194 \\
\hline AISI 316L & 161 & 174 & 169 & 191 & 175 & 192 & 188 & 179 & 170 & 159 \\
\hline AISI $316 \mathrm{Ti}$ & 171 & 175 & 187 & 176 & 181 & 180 & 195 & 182 & 184 & 182 \\
\hline AISI 321 & 168 & 171 & 179 & 172 & 172 & 166 & 177 & 169 & 175 & 168 \\
\hline
\end{tabular}

In the Table. 4 points 1,2,8,9 indicates at HAZ and the points 3, 4,5,6,7 indicates at Fusion Zone (FZ). The location of the hardness measuring points is shown in Figure.5. The variation of hardness across the weld is shown in Figure.6.

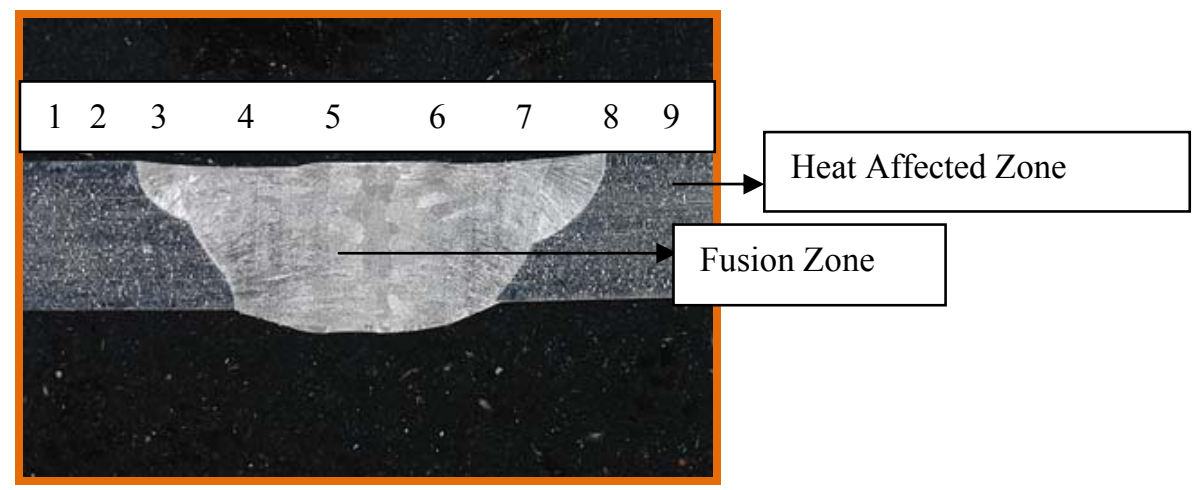

Fig.5 Location of hardness measuring points in the weld fusion zone 


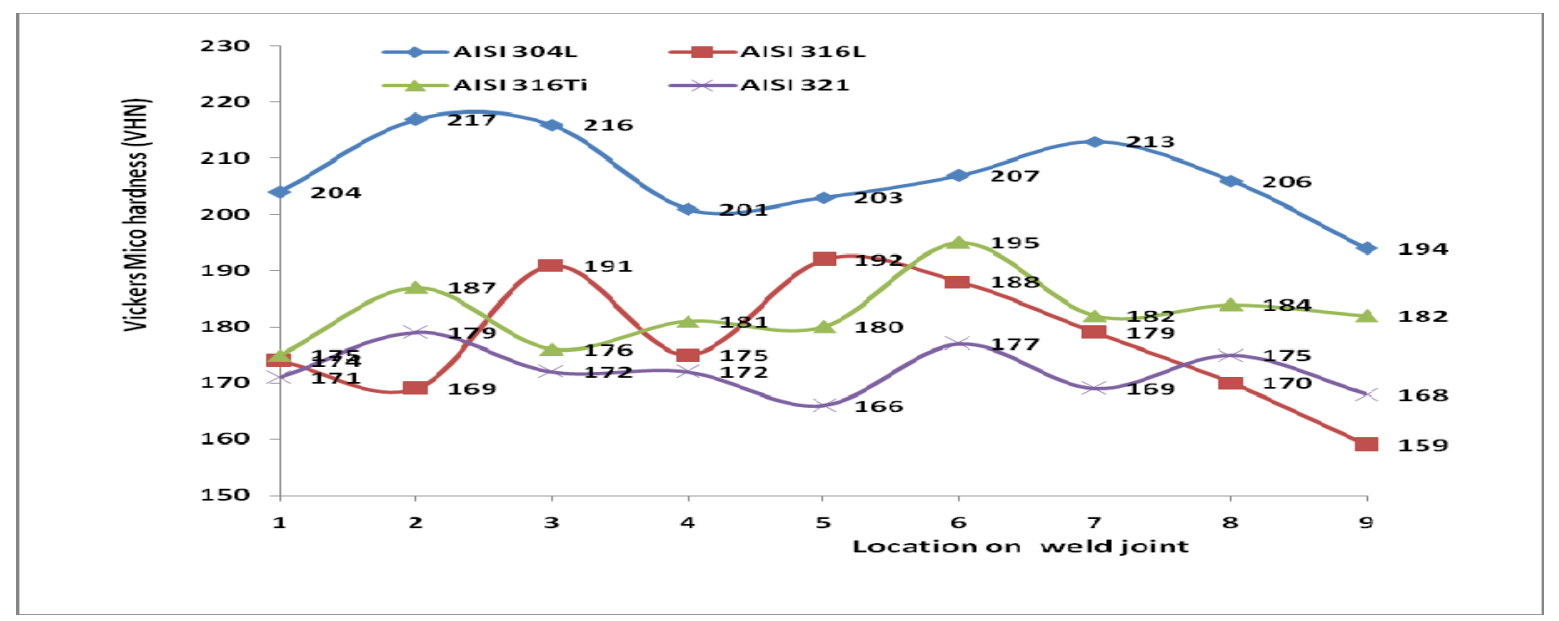

Fig.6 Variation of hardness across the weld

From Table 4 and Figure 6 it understood that hardness at centre of FZ is less and it keeps on increasing away from the centre and decreases towards HAZ. The hardness values of AISI 304L are high; whereas least is for AISI 321.The higher hardness values of AISI 304L may be due to martensite formation during welding. From Table 4, it is understood that the hardness values of the weld metal is more than the parent material hardness. It is due to grain refinement taking place in the FZ during welding because of usage of pulsing current and also because of martensentic transformation.

\subsection{Measurement of ultimate tensile strength}

Three transverse tensile specimens are prepared as per ASTM E8 guidelines and the specimens after wire cut Electro Discharge Machining are shown in Fig.7. Tensile tests are carried out in 100kN computer controlled Universal Testing Machine (ZENON, Model No: WDW-100). The specimen is loaded at a rate of $1.5 \mathrm{kN} / \mathrm{min}$ as per ASTM specifications, so that the tensile specimens undergo deformation. From the stress strain curve, the yield and ultimate tensile strength of the weld joints is evaluated and the average of three sample results for each material is presented in Table 6. During testing AISI 304L and AISI 316L failed at FZ, where as AISI 316Ti failed at FZ. The tested specimens are presented in Fig.8

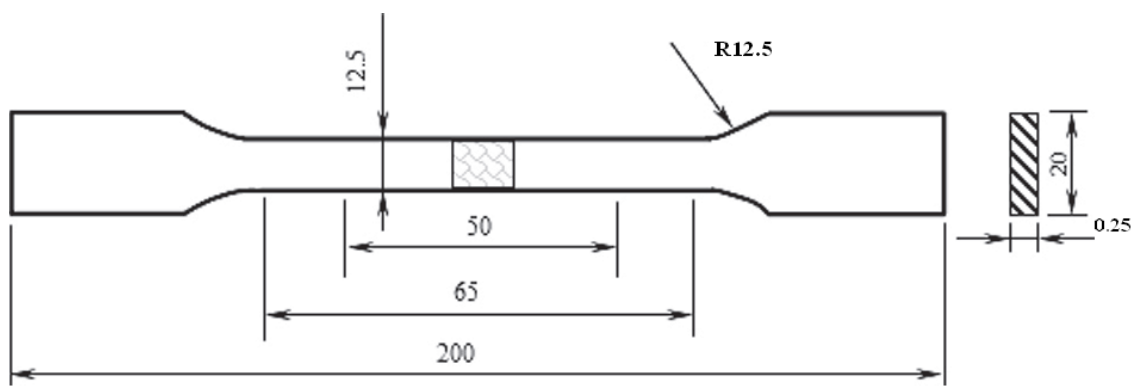

Fig.7 Schematic diagram of tensile specimen as per ASTM E8.

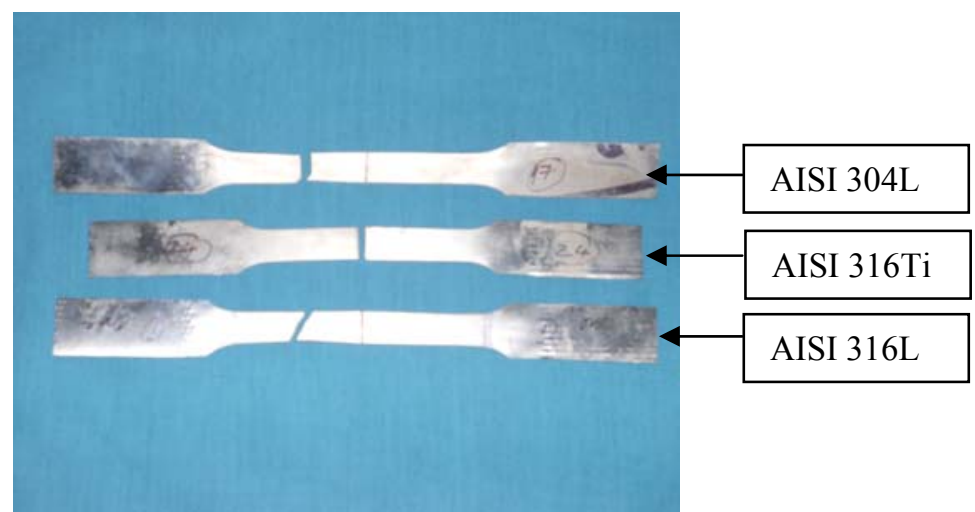

Fig.8 Tensile specimens after testing 


\section{Results \& Discussions}

The results of all the weld quality characteristics discussed in chapter 2 on the welded samples of AISI 304L, AISI 316L, AISI $316 \mathrm{Ti}$, AISI 321 are summarized and presented in Table 6.

Table 6 Comparison of weld quality characteristics

\begin{tabular}{|c|c|c|c|c|c|c|c|c|}
\hline \multirow{2}{*}{ Material } & \multicolumn{4}{|c|}{ Weld bead Geometry $(\mathrm{mm})$} & \multirow{2}{*}{$\begin{array}{c}\text { Fusion } \\
\text { Zone grain } \\
\text { size } \\
\text { (Microns) }\end{array}$} & \multirow{2}{*}{$\begin{array}{l}\text { Fusion } \\
\text { Zone } \\
\text { hardness } \\
\text { (VHN) }\end{array}$} & \multirow{2}{*}{$\begin{array}{l}\text { Yield } \\
\text { Strength } \\
\text { (MPa) }\end{array}$} & \multirow{2}{*}{$\begin{array}{c}\text { Ultimate } \\
\text { Strength } \\
\text { (MPa) }\end{array}$} \\
\hline & $\begin{array}{c}\text { Front } \\
\text { Width }(\mathrm{mm})\end{array}$ & $\begin{array}{c}\text { Back } \\
\text { Width(mm) }\end{array}$ & $\begin{array}{c}\text { Front } \\
\text { Height }(\mathrm{mm})\end{array}$ & $\begin{array}{c}\text { Back } \\
\text { Height }(\mathrm{mm})\end{array}$ & & & & \\
\hline AISI 304L & 1.509 & 1.439 & 0.060 & 0.047 & 31 & 208 & 256 & 657 \\
\hline AISI 316L & 1.408 & 1.342 & 0.052 & 0.044 & 33 & 185 & 205 & 526 \\
\hline AISI $316 \mathrm{Ti}$ & 1.225 & 1.084 & 0.048 & 0.038 & 28 & 183 & 237 & 594 \\
\hline AISI 321 & 1.134 & 0.966 & 0.046 & 0.036 & 24 & 171 & 247 & 582 \\
\hline
\end{tabular}

From Table 6, it is understood that for same welding conditions, front width, back width, front height and back height of weld bead geometry are higher for AISI 304L compared to the other austenitic stainless steels. The reason may be due to low carbon and nickel content compared to others. Higher the front width and back width in the weld bead geometry indicates complete fusion of the parent metal and hence the joint is strong. The FZ grain size of AISI 304L is around 31 microns, which is higher compared to other austenitic stainless steels. As grain size and hardness are inversely proportional to each other, AISI 304L has higher hardness of about 208VHN compared to other austenitic stainless steels. During welding the parent metal is subjected to large amount of heat, because of which the grains are disturbed and there occurs a weak zone known as HAZ, where there are more chances of failure of weld specimen during tensile test. The yield strength and ultimate tensile strength of AISI 304L welded joint are better compared to the other austenitic stainless steels and the corresponding values are $256 \mathrm{MPa}$ and $657 \mathrm{MPa}$ respectively. The higher values of AISI 304L may be due to martensite transformation taking place during welding.

Table 7 Comparison of mechanical properties of parent metal and weldment

\begin{tabular}{|l|c|c|c|c|c|c|c|c|c|}
\hline & \multicolumn{3}{|c|}{$\begin{array}{c}\text { Hardness } \\
\text { (VHN) }\end{array}$} & \multicolumn{3}{c|}{$\begin{array}{c}\text { Yield Strength } \\
\text { (MPa) }\end{array}$} & \multicolumn{3}{c|}{$\begin{array}{c}\text { Ultimate } \\
\text { Strength (MPa) }\end{array}$} \\
\hline $\begin{array}{c}\text { Material } \\
\text { grade }\end{array}$ & Parent & weldment & $\begin{array}{c}\% \\
\text { Variation }\end{array}$ & Parent & weldment & $\begin{array}{c}\% \\
\text { Variation }\end{array}$ & Parent & weldment & $\begin{array}{c}\% \\
\text { Variation }\end{array}$ \\
\hline AISI 304L & 176 & 208 & -18.1818 & 350 & 256 & 26.85714 & 784 & 657 & 16.19898 \\
\hline AISI 316L & 161 & 185 & -14.9068 & 220 & 205 & 6.818182 & 550 & 526 & 4.363636 \\
\hline AISI 316 Ti & 171 & 183 & -7.01754 & 261 & 237 & 9.195402 & 634 & 594 & 6.309148 \\
\hline AISI 321 & 168 & 171 & -1.78571 & 265 & 247 & 6.792453 & 608 & 582 & 4.276316 \\
\hline
\end{tabular}

From Table 7, it is clear that hardness of the weldment is more than the parent metal for all the steels which were considered in the present study. This may be due to martenistic transformation taking place during welding. The yield and ultimate strength values for weldment are less than the parent metals. It is due to grain coarsening taking place at HAZ. The \% variation of mechanical properties like hardness, yield strength and ultimate strength of AISI 304L is more compared to other austenitic steels considered in the study. However there is no much variation in \% variation of mechanical properties for AISI 316L, AISI 316Ti and AISI 321.

\section{Conclusions}

Pulse current MPAW was carried out successfully on various austenitic stainless steels like AISI 304L, AISI 316L, AISI 316Ti, and AISI 321 for same welding conditions and same thickness. Peak current, background current, pulse rate and pulse width are chosen as the important welding parameters in the present study and welding was carried out based on the optimal values of welding parameters obtained for AISI 304L from earlier studies. For same thickness and uniform welding conditions, it is observed that AISI 304L has better weld bead geometry, higher hardness and tensile properties compare to other stainless steels selected. The high hardness and tensile strength may be because of martensite transformation taking place during welding. The present paper is limited to comparison of static properties only, however one may consider dynamic properties like creep \& fatigue. 


\section{Acknowledgments}

The authors would like to thank Shri. R.Gopla Krishnan, Director, M/s Metallic Bellows (I) Pvt Ltd, Chennai for his support to carry out experimentation work.

\section{References}

Ahmad M., Akhter J. I., Akhtar M., Iqbal M., 2007. Microstructure and characterization of phases in TIG welded joints of Zircaloy-4 and stainless steel 304L, Journal of Materials Science, Vol. 42, No. 1, pp. 328-331.

Balasubramanian.M, Jayabalan.V, Balasubramanian.V, 2010. Effect of process parameters of pulsed current tungsten inert gas welding on weld pool geometry of titanium welds, Acta Metallurgica Sinica (English Letters), Vol. 23, No. 4, pp. 312-320.

Balasubramanian.B, Jayabalan.V, Balasubramanian.V, 2006. Optimizing the pulsed current gas tungsten arc welding parameters, Journal of Material Science and Technology, Vol. 22, No. 6, pp. 821-825.

David S.A., Goodwin G.M. and Braski D.N., 1979. Solidification behavior of austenitic stainless steel filler metals, Welding Journal, Vol. 58, No. 11, p. 330-s - 336-s.

Giridharan P. K. and Murugan N., 2009. Optimization of pulsed GTA welding process parameters for the welding of AISI 304L stainless steel sheets, The International Journal of Advanced Manufacturing Technology, Vol. 40, No. 5-6, pp. 478-489.

Lee W.-S., Lin C.-F., Liu C.-Y., Chin-Wei Cheng C.-W., 2004. The effects of strain rate and welding current mode on the dynamic impact behavior of plasma-arc-welded 304L stainless steel weldments, Metallurgical and Materials Transactions A, Vol. 35, No. 5, pp. 1501-1515.

Malik R.K., 1981. HIP heals defects in austenitic stainless steel welds, Metal Progress, Vol. 119, No. 4, p.86.

Palaniappan M., Subbaratnam R., Baskaran A., Chandramohan R., 1996. Effect of repeated repairs on the stainless steel welds upon the ultrasonic examination sensitivity, 14th World Conference on Non Destructive Testing, New Delhi, India, 8 - 13 December.

Prasad K.S., Rao C.S., Rao D.N., 2011a. Prediction of weld pool geometry in pulsed current micro plasma arc welding of SS304L stainless steel sheets, International Transaction Journal of Engineering, Management, and Applied Sciences and Technologies, Vol. 2, No. 3, pp. 325-336.

Prasad K.S., Rao C.S., Rao D.N., 2011b. A study on weld quality characteristics of pulsed current micro plasma arc welding of SS304L sheets, International Transaction Journal of Engineering, Management, and Applied Sciences and Technologies, Vol. 2, No. 4, pp. 437-446.

Prasad K.S., Rao C.S., Rao D.N., 2011c. Optimizing fusion zone grain size and ultimate tensile strength of pulsed current micro plasma arc welding welded SS304L Sheets Using Hooke \& Jeeves Algorithm, Proceedings of International Conference on Futuristic Trends in Materials and Energy Systems, V R Siddhartha Engineering College, Vijayawada, A.P., India,p.112.

Prasad K.S., Rao C.S., Rao D.N., 2012. Establishing empirical relations to predict grain size and hardness of pulsed current micro plasma arc welded SS 304L Sheets, American Transactions on Engineering and Applied Sciences,Vol.1, No.1, pp. 57-74.

Reddy K.G., 2000. Analysis of corroded austenitic stainless steel welds, Praktishe Metallographie (Practical Metallurgy), Vol. 37, No. 11, p. 600.

Sadek A.Z., El-Sheikh A.M., 2000. Failure analysis of SS 304 weldments by metallurgically enhanced stress corrosion cracking in laboratory environments, Corrosion 2000, Orlando.

Singh P.J., Achar D.R.G, Guha B , Nordberg H. 2003. Fatigue life prediction of gas tungsten arc welded AISI 304L cruciform joints with different LOP sizes, International Journal of Fatigue, Vol. 25, No. 1, pp. 1-7.

Sonsuvit N., Somrerk C.-A., Gobboon L., 2005. Effects of TIG pulse welding parameters and nitrogen gas mixed in argon shielding gas on weld bead formation and microstructure of weld metals of AISI 304L stainless steels at the 10-h welding position, Session PE3: Pipeline Symposium: Properties \& Structures.

Vannan K.V., Thangavel B., 1978. Occurrence of delta ferrite in type 304/304L stainless steel pipe welds, The Third International Symposium of the Japan Welding Society, Tokyo, Japan .

Velasco F, Blanco G, Bautista A, Martinez_M.A., 2009. Effect of welding on local mechanical properties of stainless steels for concrete structures using universal hardness tests, Construction and Building Materials, Vol. 23, No. 5, pp. 1883-1891.

\section{Biographical notes}

Kondapalli Siva Prasad is currently an Assistant Professor in the Department of Mechanical Engineering, Anil Neerukonda Institute of Technology \& Sciences, Visakhapatnam,India. He graduated in Mechanical Engineering from Vasavi Engineering College (Affiliated to Osmania University, Hyderabad) in 2000. He received his Masters Degree from JNTU Hyderabad, India in 2002. He has published 16 research papers in International Journals and various papers in International and National conferences.

Chalamalasetti Srinivasa Rao is currently an Associate Professor in the Department of Mechanical Engineering, Andhra University, Visakhapatnam, India. He graduated in Mechanical Engineering from SVH Engineering College, Machilipatnam,, India in 1988. He received his Masters Degree from MANIT, Bhopal, India in 1991. He received $\mathrm{PhD}$ from Andhra University in 2004. He has published over 25 research papers in refereed journals and conference proceedings. 
Damera Nagesawara Rao worked as a Professor in Andhra University, Visakhapatnam, India for past 30 years and presently he is working as Vice Chancellor, Centurion University of Technology \& Management, Odisha, India. Under his guidance $19 \mathrm{PhDs}$ were awarded. He has undertaken various projects sponsored by UGC, AICTE and NRB. He worked as a coordinator for Centre for Nanotechnology, Andhra University, Visakhapatnam.

Received March 2012

Accepted August 2012

Final acceptance in revised form September 2012 